\title{
Effect of Cooling Rate on Ordering Behavior in a CuPt Alloy
}

\author{
Kunihiro HISATSUNE*, Michio OHTA and Masaji YAMANE
}

Department of Dental Materials Engineering, School of Dentistry, Kyushu University, Fukuoka 812, Japan *Present address: Department of Dental Materials Science, Nagasaki University School of Dentistry, Nagasaki 852, Japan

Received on September 13, 1982

Some amount of transformation was achieved by the consumption of excess-vacancies during cooling. Homogeneous ordering resulted from the formation of microdomains in the grain interior. Hardening is due to the strain caused by the difference in crystal structure and by the fine domain size.

Key Words: CuPt, Ordering, Cooling rate

\section{INTRODUCTION}

Copper-platinum alloys near the equiatomic composition $\mathrm{CuPt}$ are well known to be age-hardenable. ${ }^{1)}$ The equiatomic alloy $\mathrm{CuPt}$ which has a face-centered cubic structure above the critical temperature $\left(\mathrm{T}_{\mathrm{c}}\right)$ of about $824^{\circ} \mathrm{C}^{2,3)}$ becomes an ordered structure below this temperature. The ordered lattice has a face-centered rhombohedral structure which consists of alternating sheets of copper and platinum atoms in parallel (111) planes.")

Recently, some studies on the ordering mechanisms of $\mathrm{CuPt}$ alloys have been reported. ${ }^{5 \sim 8)}$ With respect to the morphology of the ordering in these alloys, two modes are recognized, namely, ordering at the grain boundary and in the grain interior. According to Mitchell et al. ${ }^{7)}$ and Torfs et al. ${ }^{8)}$, specimens quenched from above $T_{c}$ show sharp superlattice spots in electron diffraction patterns. This fact suggests that it is very difficult to suppress ordering during quenching. Therefore, the effect of cooling rate on ordering in $\mathrm{CuPt}$ alloys must be investigated. We have already reported on the effect of the quenching temperature on ordering behavior in CuPt alloys. ${ }^{9)} \quad$ The results indicated that the difference in cooling rate is an important factor for the ordering process.

The purpose of this study is to clarify the effects of various cooling rates on ordering in CuPt alloys.

\section{MATERIALS AND METHODS}

Wire specimens $\left(1 \mathrm{~mm}^{\phi}\right)$ were prepared from $99.95 \% \mathrm{Pt}$ and $99.99 \% \mathrm{Cu}$. The chemical composition of the alloy used in this study was $49.37 \mathrm{at} \% \mathrm{Cu}$ and $50.63 \mathrm{at} \% \mathrm{Pt}$, which is very close to the equiatomic alloy of $\mathrm{CuPt}$.

The alloy was disordered at $900^{\circ} \mathrm{C}$ and ordered by cooling at various rates. These cooling modes are listed in Table 1. The notation of the mode is in descending order of the cooling rate, namely, "A" has the fastest cooling rate and "I" the slowest. The effect of the cooling rate on ordering in CuPt was studied by means of electrical resistivity measurements, hardness tests, X-ray diffraction, and electron microscopic observations. 
Table 1 Cooling modes used

\begin{tabular}{c|l}
\hline Notation of Mode & \multicolumn{1}{c}{ Mode of Cooling } \\
\hline A & iced-brine-quenching (naked specimen) \\
\hline B & iced-brine-quenching (in silica tube) \\
\hline C & air-cooling (naked specimen) \\
\hline D & air-cooling (in silica tube) \\
\hline E & air-cooling (in double silica tube) \\
\hline F & air-cooling (in large silica tube) \\
\hline G & cooling at the rate of $25^{\circ} \mathrm{C} / \mathrm{min}$ \\
\hline H & cooling at $1^{\circ} \mathrm{C} / \mathrm{min}$ \\
\hline I & cooling at $0.1^{\circ} \mathrm{C} / \mathrm{min}$ \\
\hline
\end{tabular}

Electrical resistivity measurements were made in vacuo using a 4-terminal apparatus with a constant current of $0.5 \mathrm{~A}$. The specimens were $1 \mathrm{~mm}^{\phi} \times 50 \mathrm{~mm}$ length with $\mathrm{Ni}$ leads welded at each end.

Hardness tests were made using a diamond pyramid hardness indentor with a 500-gram load. The Vickers hardness results are the average of at least five indentations.

For X-ray diffraction, a minus 300 mesh powder was prepared from the alloy by filing. The powdered specimen was sealed in an evacuated silica tube, disordered at $900^{\circ} \mathrm{C}$, and cooled to room temperature at various rates. An X-ray diffractometer* was employed. Conditions of $\mathrm{X}$-ray diffraction used were as follows: $\mathrm{Cu}$ target; $\mathrm{Ni}$ filter; tube voltage, $45 \mathrm{kV}$; tube current, $80 \mathrm{~mA}$; time constant, 2 or $10 \mathrm{~s}$; scanning speed, 1 or $0.5^{\circ} \mathrm{C} / \mathrm{min}$; chart speed, 10 or $40 \mathrm{~mm} / \mathrm{min}$; receiving slit, $0.3 \mathrm{~mm}$.

Specimens for electron microscopy were prepared by using an ion beam thinning technique. Thin foils were examined at $1000 \mathrm{kV}$ in a JEM-1000 microscope.

\section{RESULTS}

\section{(1) Cooling curves}

Figure 1 shows the variations of electrical resistivity at various cooling rates. The drastic decrease of resistivity at the vicinity of $T_{c}$ may be due to the ordering. It is clear that the degree of ordering at room temperature is different at various cooling rates. The slower the cooling rate, the further the ordering proceeds. At rates of less than $25^{\circ} \mathrm{C} / \mathrm{min}$, the disorder-to-order transformation was mostly completed. On the other hand, by waterquenching (A) the ordering reaction was suppressed. A state intermediate between them was obtained by air-cooling (E).

(2) Hardness tests

Figure 2 shows the effect of the cooling rate on hardness. The highest value of hardness was obtained by air-cooling (E). With rates both faster and slower rates than that of air-

* RU-100PL, Rigaku Denki Co. Ltd., Tokyo, Japan 


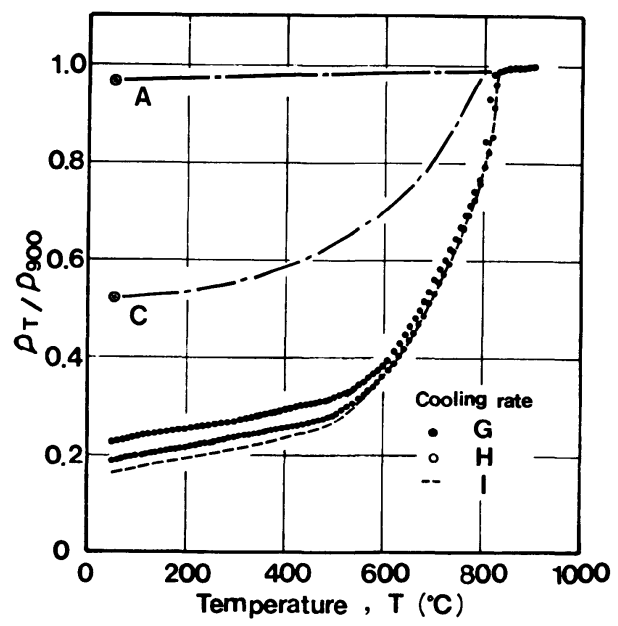

Figure 1 Electrical resistivity changes during cooling at various rates

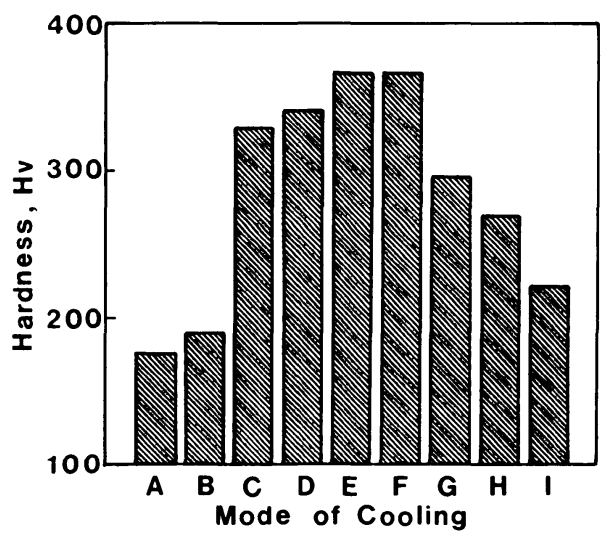

Figure 2 Variations in microvickers hardness values with cooling rate

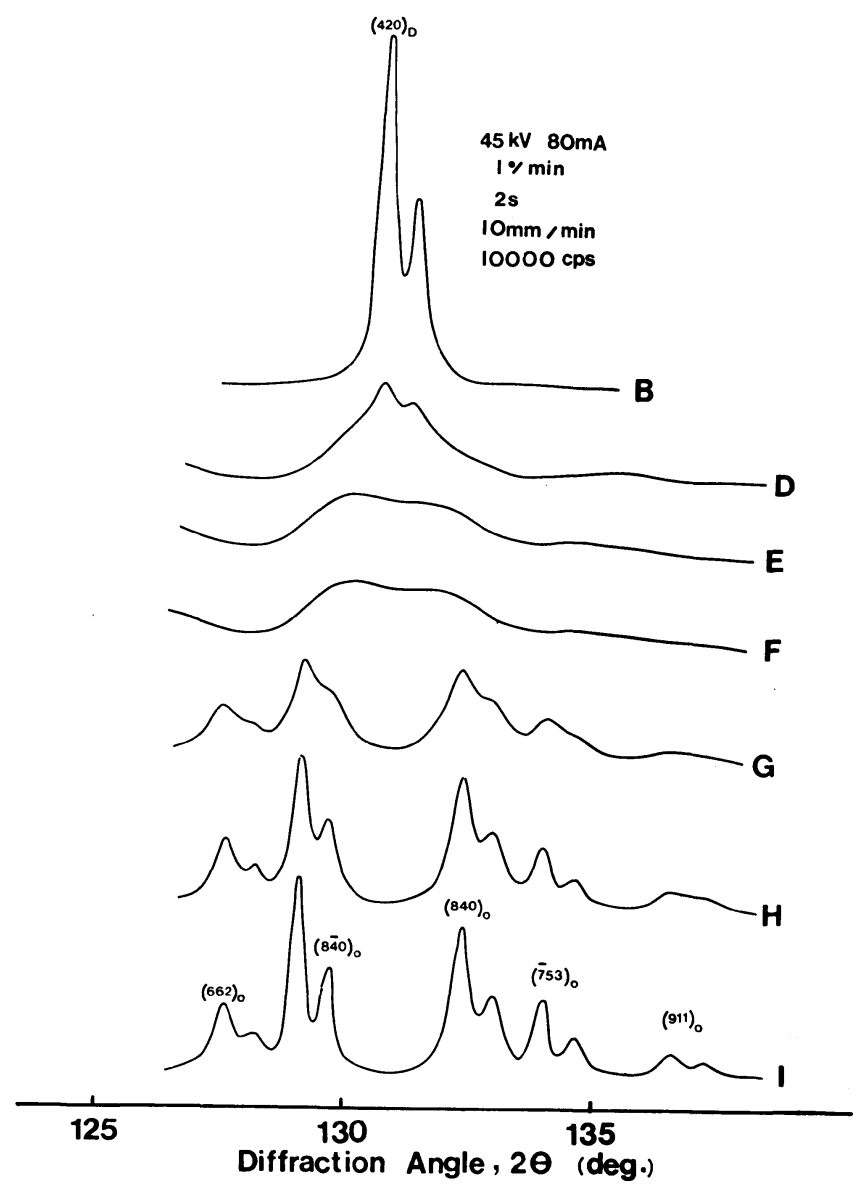

Figure 3 Variations in X-ray line profiles with cooling rate 
cooling, lower values were obtained. It is clear that the peak value for hardness is attained by an intermediate cooling rate.

(3) X-ray diffraction

Figure 3 shows the X-ray line profiles of the specimen cooled at various rates. By the ordering of $\mathrm{CuPt}$, superlattice lines appeared and also the fundamental ones began to split, namely $(420)_{D} \rightarrow(8 \overrightarrow{40})_{0}+(840)_{0}$. Subscripts $O$ and D refer to the ordered and disordered phases, respectively. The iced-brine-quenched specimen (B) showed only the $(420)_{D}$ reflection, indicating a disordered state. The air-cooling (E) mode gave very broad line profiles, and the superlattice reflection (753) appeared at a higher diffraction angle side. It is obvious that ordering of $\mathrm{CuPt}$ occurred during air-cooling. The slower the cooling rate, the sharper is the X-ray line profile. These results well explain the variations of hardness shown in Figure 2.

(4) Microstructure

Figure 4 shows transmission electron micrographs of the air-cooled specimen, which was taken from the specimen having the peak hardness value (E). (a) represents the brightfield image and (b) is the dark-field one by using a (111)o superlattice spot. (c) is the selected

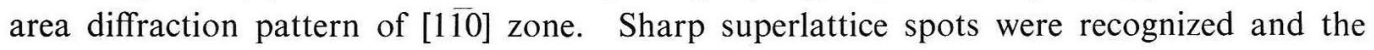
dark-field image indicated the existence of very finely ordered domains.

(a)

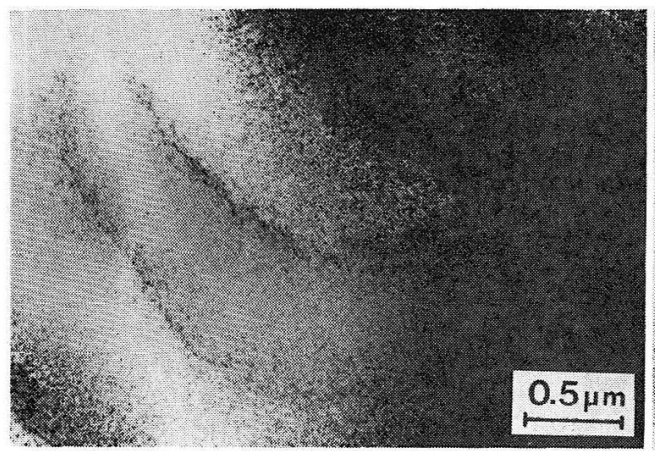

(c)

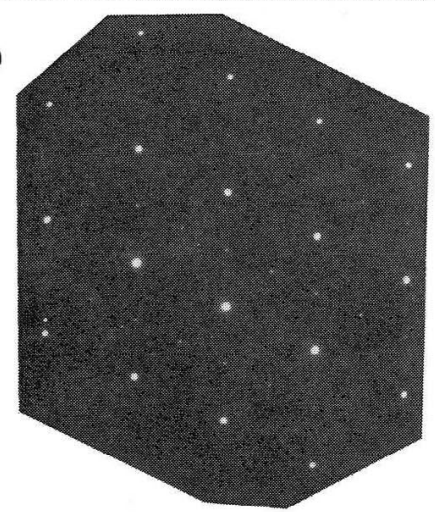

(b)

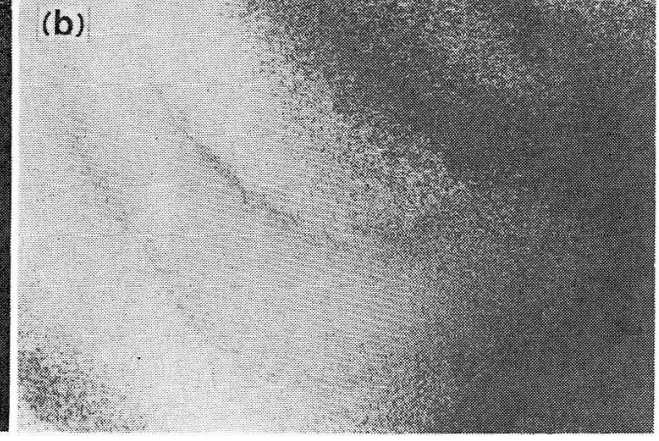

Figure 4 Bright-field image (a), dark-field image (b) and the selected area diffraction pattern (c) of the $\mathrm{CuPt}$ alloy air-cooled from $900^{\circ} \mathrm{C}$. Incidental beam [1 $\left.\overline{1} 0\right]$ 


\section{DISCUSSION}

(1) Ordering behavior during cooling

From Figures 1-3, it is noted that the difference in cooling rate changes the degree of the order at room temperature. Figure 5 shows anisothermal heating curves of electrical resistivity and their temperature derivatives after cooling at various rates. A heating rate of $1{ }^{\circ} \mathrm{C} / \mathrm{min}$ was employed. In the quenched specimen (B) the electrical resistivity started to decrease at about $200^{\circ} \mathrm{C}$ and dropped steeply at around $300^{\circ} \mathrm{C}$. This large decrease can be divided into two stages. Thereafter, this curve met the previous cooling curve at the rate of $0.1^{\circ} \mathrm{C} / \mathrm{min}$ until the disordered state was attained. This behavior is much more clearly seen in the temperature derivative curve (Figure $5(\mathrm{~b})$ ). If $\mathrm{d} \rho / \mathrm{dT}$ is considered to be proportional to the specific heat, ${ }^{10)}$ two exothermic, and one endothermic peaks are found in Figure 5(b). The former correspond to the ordering and the latter to the disordering. We have already reported that two exothermic ordering reactions were due to the migration of quenched-in excess vacancies and of equilibrium vacancies, respectively. ${ }^{11}$

On the one hand, the air-cooled specimen (D) showed only one exothermic and one endothermic peak on its temperature derivatives curve. The first exothermic peak (stage I) was not present. We have already reported that stage I corresponds to the ordering by

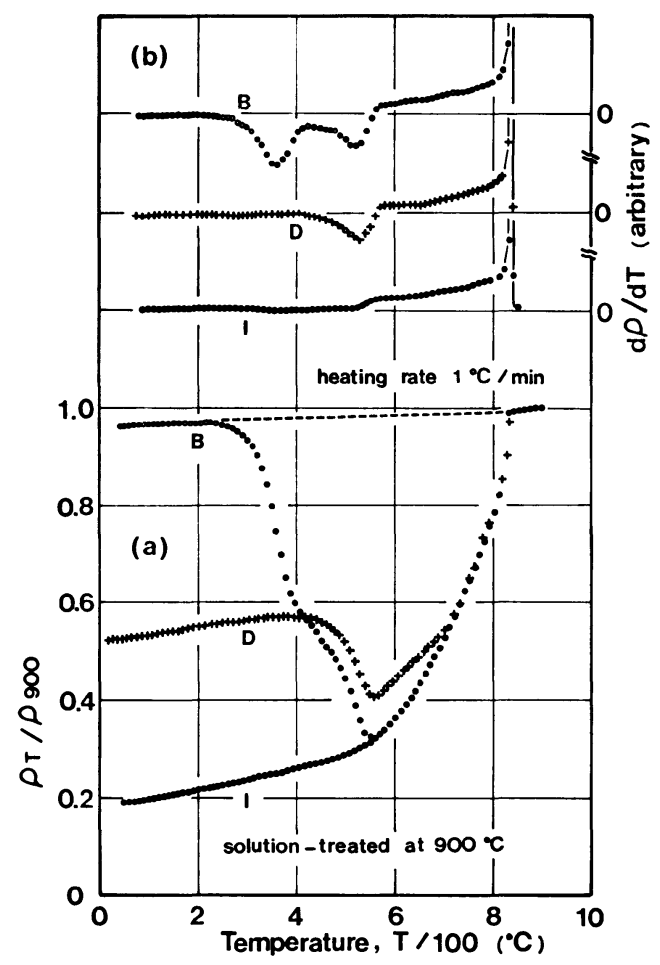

Figure 5 Anisothermal annealing curves (a) of electrical resistivity and their temperature derivatives (b) after cooling from $900^{\circ} \mathrm{C}$ at various rates 


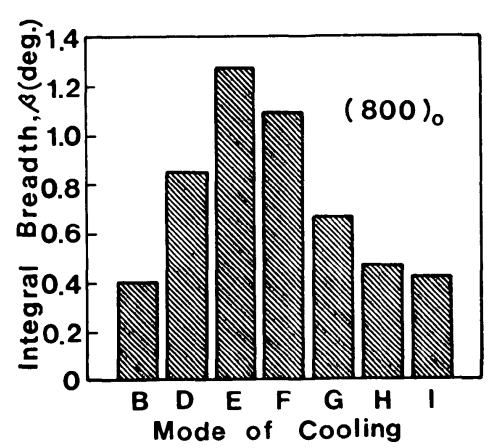

Figure 6 Variations in integral breadth, $\beta$, with cooling rate

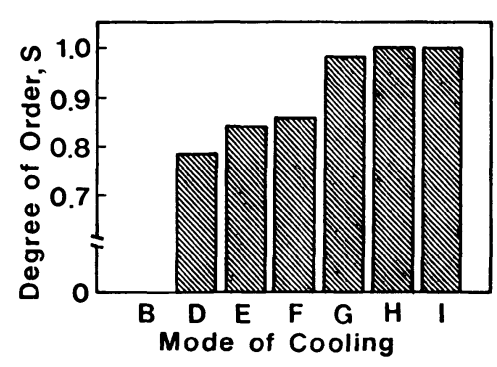

Figure 7 Variations in the degree of order with cooling rate. B suppressed the ordering, i.e., $S=0$

the annihilation of quenched-in excess vacancies. ${ }^{11)}$ Accordingly, it is supposed that some amount of ordering develops during air-cooling by the consumption of excess vacancies.

On the other hand, it is proposed that sufficient ordering can be obtained by slow cooling

(I). Both exothermic peaks had completely disappeared on the $\mathrm{d} \rho / \mathrm{dT}$ curve in this case.

(2) Order-hardening during cooling

Hardness changes of the specimen cooled at various rates indicate that an intermediate cooling rate gives a maximum value. The most rapid cooling (A) produced a disordered and softened state. The slowest cooling (I) rate produced a perfectly ordered state, but it was a softened state, too. The intermediate state of ordering is responsible for the orderhardening in CuPt.

Figure 6 shows the variations in the integral breadth of $(800)_{0}$ reflection of X-ray diffraction with various modes of cooling. It is very similar to the hardness changes seen in Figure 2. Mode E indicated the maximum broadening. This broadening is thought to be due to the strain accompanied with ordering and to the fine domain (Figure 4). When the ordered CuPt structure is formed in the disordered matrix, a considerable amount of strain is introduced because of the transformation from a face-centered cubic lattice into a facecentered rhombohedral lattice. ${ }^{1,4)}$ It is evident that the hardening during cooling was caused by ordering and by fine domain size.

Figure 7 shows the variations in the degree of order $\mathrm{S}$ calculated from the ratio of the integrated intensity between the superlattice reflection $(331)_{0}$ and the fundamental one $(400)_{0}$. It is noted that maximum hardness was obtained at $S=0.85(E)$. As cooling slower than mode $\mathrm{E}$ will produce the growth of ordered domains, the release of strain in ordered CuPt is expected. In fact, many twins were observed in the slow-cooled specimen (I), which was completely ordered.

\section{CONCLUSION}

Ordering behavior in the equiatomic alloy $\mathrm{CuPt}$ at various cooling rates was investigated by means of electrical resistivity measurements, hardness tests, and X-ray diffraction.

The main results obtained were as follows:

(1) By air-cooling from above the critical temperature, a degree of ordering was achieved 
by the consumption of excess vacancies during cooling. A considerable amount of hardening was also attained by some cooling rates.

(2) The transformation is the homogeneous ordering resulting from the formation of microdomains in the grain interior. The hardening is thought to be due to the strain caused by the difference in the crystal structure between ordered and disordered states and by the fine domain size.

\section{ACKNOWLEDGEMENT}

The authors wish to thank Prof. K. Yasuda for stimulating discussions.

\section{REFERENCES}

1) Nowack, L.: Vergütbare Edelmetall-Legierungen, Z. Metall., 22: 94-103, 1930.

2) Geiken, G.W.: USAEC Rept. UCRL-17615, 1967 (M.S. Thesis, University of California).

3) Hisatsune, K., Ohta, M. and Yamane, M.: Coexistent region of ordered and disordered phases in CuPt, Scripta Met., 11: 563-564, 1977.

4) Johansson, C.H. und Linde, J.O.: 1. Gitterstruktur und elektrisches Leitvermögen der MischkristalIreihen Au-Cu, Pd-Cu und Pt-Cu, Ann. Phys., 82: 449-479, 1927.

5) Irani, R.S. and Cahn, R.W.: Order-hardening of CuPt, Acta Met., 21: 575-584, 1973.

6) Irani, R.S. and Cahn, R.W.: The mechanism of crystallographic ordering in CuPt, J. Mat. Sci., 8: 1453-1472, 1973.

7) Mitchell, R., Paris, H.G. and Lefevre, B.G.: Order hardening in equiatomic CuPt, Met. Trans., 4: 833-840, 1973.

8) Torfs, E., Van Landuyt, J., Stals, L. and Amelinckx, S.: The ordering mechanism in CuPt as studied by electrical resistance measurements and electron microscopy, Phys. Stat. Sol. (a). 31: 633-645, 1975.

9) Hisatsune, K., Ohta, M. and Yamane, M.: The effects of quenching temperature on the ordering in equiatomic CuPt alloy, J. Japan Inst. Met., 43: 93-96, 1979, (in Japanese).

10) Kuroki, H., Matsuda, H. and Eguchi, T.: A study of the $550^{\circ} \mathrm{C}$-change in ordered $\mathrm{FeCo}$ alloy through electrical resistivity and specific heat measurements, J. Japan Inst. Met., 38: 8-14, 1974, (in Japanese).

11) Hisatsune, K.: A study of the ordering process in equiatomic CuPt alloy by anisothermal annealing method, J. Japan Inst. Met., 42: 118-124, 1978, (in Japanese). 


\title{
本号掲載論文の和文抄録
}

\author{
Cupt の規則化に及ぼす冷却速度の影響 \\ 久恒邦博*, 太田道雄, 山根正次 \\ 九州大学歯学部歯科理工学講座 \\ *現在 : 長崎大学歯学部歯科理工学講座
}

等原子比合金 $\mathrm{CuPt}$ の規則化について, 臨界温度以上 $\left(900^{\circ} \mathrm{C}\right)$ から室温まで種々の速度で冷却した場合の影響 を電気抵抗測定, 硬さ試験, X線回折, 透過型電子顕微 鏡により検討した。水中冷却した武料は完全な不規則相 （f $\mathrm{fc}_{\mathbf{c c}}$ )であったが, 空冷した試料は冷却中にかなりの則

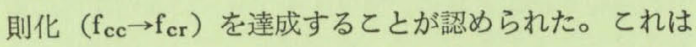

過剩空孔の消費に伴なう規則化である。冷却速度が遅く なるにつれて規則度は上昇し， $-25^{\circ} \mathrm{C} / \mathrm{min}$ 以下におい ては完全な規則状態が得られた。規則化による硬化の寄 与は中間の泠却速度である空冷武料でピークが認められ た。この硬さピークに対応する規則化は粒内におけるマ イクロドメインの形成に起因する均一反応であった。

マグネンア系埋没材による純チタンおよびチタン合金の歯科鋳造について

井田一夫*, 都賀谷紀宏*, 堤 定美*, 竹内正敏*

*京都大学医用高分子研究センター歯科材料応用研究部門

純チタンおよびチタンを主成分とする合金は，耐食性 や生体適合性が非常によいとと, 軽いとと,などの特徽 を有するので，歯科におけるクラウン・ブリッジ用，床 用，インプラント用などの材料として興味のある金属で ある。

しかし，融点が高いととや高温における反応性が大き いとと,などのために鋳造が極めて困難であり，てれま で歯科用金属として使用されていなかった。

本研究は, 新しい鋳造機 “CASTMATIC” を使用し, マグネシアを主成分とする埋没材を使用して純チタンお
よびチタン合金を鋳造し，鋳造物の機械的性質，表面性 状などを検討したものである。またマグネシア系埋没材 の物理的性質も検討した。

実験の結果，この方法で鋳造した純チタンは金合金 （硬質）に近い機械的性質を示し, 鋳肌のよいものが得 られた。またインプラント用ブレード, クラウン, ブ リッジなど臨床用のパターンにおいてあ外観のきれいな 鋳造体を得ることができた。しかし寸法精度については 更に検討が必要である。

\section{コンポシットレンジの marginal fracture toughness について}

谷 嘉明

京都大学医用高分子研究センター 歯科材料応用研究部門

歯科用修復材の縁端強度は臨床的に重要な性質である あのの，その測定法は確立されていない。本報では，粉 末治金工業の分野で，圧粉体の成形性を測定する規格試 験法として用いられている Rattler 陚験法を応用して, 各種コンポジットレジンの marginal fracture toughness を評価した。各材料について, $6 \times 6 \times 3 \mathrm{~mm}$ の角片 5 個 づつ作製し, Rattler 試験機の青銅金龬製シリンダー
ケージの中に入れ， 87 r.p.m の回転速度で 10,000回転さ せて, 試片の縁端部を磨滅させた。試験前の試片重量に 対する試験後の重量損失率を求めた。重量損失率の小さ いものほど marginal fracture toughness にすぐれてい ることになる。

実験の結果，MFR があっとあすぐれ，次いで日歯用 コンポジットレジンで, 従来型コンポジットレジンが 